\title{
Conflicting language ideologies and contradictory language practices in Singaporean bilingual families
}

Article

Accepted Version

Curdt-Christiansen, X.-L. (2016) Conflicting language ideologies and contradictory language practices in Singaporean bilingual families. Jounal of Multilingual and Multicultural Development, 37 (7). pp. 694-709. ISSN 01434632 doi: https://doi.org/10.1080/01434632.2015.1127926 Available at https://centaur.reading.ac.uk/52365/

It is advisable to refer to the publisher's version if you intend to cite from the work. See Guidance on citing.

Published version at: http://www.tandfonline.com/loi/rmmm20

To link to this article DOI: http://dx.doi.org/10.1080/01434632.2015.1127926

Publisher: Taylor and Francies

All outputs in CentAUR are protected by Intellectual Property Rights law, including copyright law. Copyright and IPR is retained by the creators or other copyright holders. Terms and conditions for use of this material are defined in the End User Agreement.

www.reading.ac.uk/centaur 
Central Archive at the University of Reading

Reading's research outputs online 
Title: $\quad$ Conflicting language ideologies and contradictory language practices in Singaporean multilingual families

\section{Author: $\quad$ Xiao Lan Curdt-Christiansen \\ Contact: Institute of Education, University of Reading, L33-112, Reading RG1 5EX, UK. \\ Email: $\quad$ x.l.curdt-christiansen@reading.ac.uk \\ Telephone: $\quad+44(0) 1183782766$}

With a population of 5.08 million (Statistics Singapore 2010), Singapore hosts three major ethnic groups - Chinese (76\%), Malays (13\%), and Indians (8\%) together with a small minority of others (3\%). This ethnic make-up, however, is not reflected in the linguistic practices one would expect to be associated with such ethnic diversity. The government's top-down language interventions and language-in-education policy have resulted in a somewhat different situation. Although both English and mother tongues (Mandarin, Malay and Tamil) are recognized as official languages, English enjoys a privileged position as the language of law, administration and commerce. With regard to the context of education, English has been implemented as the medium of education in all schools across all subjects. Mother tongues (MTs) are now only taught as a 'second language' and given a limited curriculum time. At a practical level, the privilege of English is reflected through better job opportunities and easier socioeconomic advancement. As a consequence, a visible shift away from MTs towards English among all ethnic groups has occurred during the past three decades (Curdt-Christiansen, 2014a; Li, Saravanan, \& Ng, 1997; Zhao \& Liu, 2008). The present language situation is less diversified compared to thirty years ago and shows a tendency towards a more linguistically homogeneous society where English is used in almost all domains, especially among young people (Chew, 2014; Curdt-Christiansen, 2014a; Gupta, 2008; Zhao \& Liu, 2008; 2010).

This study is situated against the broad background of the language shift phenomenon in Singapore in recent years. It examines through the lens of family language policy (FLP) the characteristics of linguistic practices in Singaporean families, as well as a wide variety of linguistic and non- linguistic circumstances that influence such practices. Focusing on three families, a 
Chinese, a Malay and an Indian family, representing the main ethno-linguistic make-up of the country, it attempts to explore how language ideologies as underlying forces determine parental decisions on which language to practice in their homes. In particular, it aims to examine what these families do and do not do and what they claim to do and not to do with regard to their language ideologies and linguistic practices in day-to-day interactions.

This study emphasises that both internal linguistic mechanisms such discourse strategy (Lanza, 2004) and external social forces are crucial in combatting language shift and facilitating bilingual development. It aims at enhancing our understanding that family language policy as a private family matter is "rarely a neutral, uncontested state of affairs" (Garrette, 2011, p. 516), rather, it is associated with broad processes of social development and language change that gives priority to social prestige, educational empowerment, and socioeconomic gains (Canagarajah, 2008; Curdt-Christiansen, 2009; 2012; King \& Fogle, 2013).

\section{Language ideologies and language practices}

Language ideologies are social constructs that reflect historical roles, economic values, political power and social functions of a particular language (Blommaert, 2006; Curdt-Christiansen, 2014a; Gal \& Woolard, 2001; King, 2000; Kroskrity, 2010). They are language users' evaluative perceptions and conceptions of language and language practices, based on their beliefs and assumptions about the social utility, power and value of a language in a given society (Curdt-Christiansen, 2009; Kroskrity, 2010; Schiffman, 2006). English, for example, has gained both political power and economic value as a result of globalization in recent years as evidenced by its role in international organisations, academic publications, and gate keeping to education, as well as its function in providing upward social mobility in many non-English speaking countries. 
Within the study of family language policy, researchers have explored the role of language ideology as the driving force and language belief as the source underlying the formation of a family language policy. Recent research has investigated how government policies (Curdt-Christiansen, 2014b; Lane 2010; Seloni \& Sarfati, 2013), public discourse (Okita, 2002; Garrett, 2011), parental immigrant experiences (Curdt-Christiansen, 2009; Li Wei, 1995), immigration pressure (Canagarajah 2008), language learning experiences (King \& Fogle, 2006) and parental 'impact beliefs' (De Houwer, 1999; Pérez Báez, 2013) influence FLP.

Policy at the state level is often one of the most influential factors that contributes to parental decisions on whether they "provide continuity for intergenerational transmission and resistance to language shift" (Curdt-Christiansen, 2013a, p. 3). Lane (2010), for example, showed how a minority group of Kven speakers in Norway were 'coerced' to change their FLP by ceasing to use Kven to the younger generation as a result of the official Norwegianization policy. In her study of Chinese-English bilingual families in Singapore, Curdt-Christiansen (2014b) also found that FLPs are constantly interacting with and shaped by the national language policy and the language-ineducational policy. When facing the sociopolitical and educational realities in Singapore, the parents had little choice but to place Chinese and English into an opposing position resulting in lower expectations for their children's Chinese proficiency and less sufficient provision of Chinese literacy resources.

While macro political decisions have a strong influence on FLPs, parental beliefs about their children's ability can be a decisive factor informing FLPs at micro level. Such micro level beliefs are instantiated through parental expectations of their children's bilingual development or what De Houwer called 'impact beliefs' where parents see themselves as more or less capable of and responsible for raising bilingual children. Pérez Báez (2013) studied language shift of speakers of San Lucas Quiavini Zapotec within the home and diaspora context in Mexico and California. She found that parents held weak impact beliefs in their ability to support their children's bilingual 
development leading to ineffective FLPs and language shift in both home context and diaspora community.

Also situated in diaspora context examining the ideological factors that contribute to minority language maintenance, Curdt-Christiansen (2009) identified strong parental impact beliefs by studying Chinese immigrant families in Quebec. The parents in her study held strong beliefs that providing linguistic conditions for multilingual development was equal to opening "a window to the world" (p. 367). The findings revealed that parents' perceptions of multilingual proficiency were clearly related to the market values of the different languages in Canada and beyond. Importantly, the parents' high educational expectations and aspirations for their children were the major contributing factors that informed FLPs with regard to the children's academic success and multilingual development.

Raising bilingual children and achieving additive bilingualism have become many parents' goals and desired objectives. King and Fogle (2006) interviewed 24 middle-class families in the United States with regard to their ideologies about languages and parenting that framed their FLPs. Their findings revealed that parents' positive perception of additive bilingualism in Spanish-English was influenced by their own personal experiences with regard to language learning and were linked to their identities as 'good' parents. The notion of 'good' or 'bad' parenting is inextricably connected to decisions on FLP. Okita (2002), for example, documented the 'invisible work' that Japanese mothers provided for their children's bilingual development in Japanese and English.

Within a given society or family, however, there can be many ideologies which agree or disagree with each other, sometimes causing conflicting views about languages (King et al., 2008; Shohamy, 2006; Spolsky, 2004) and leading to contradictory language practices and management interventions. King et al. (2008) succinctly put forth that "the family sphere can become a crucible for such ideological conflicts" (p. 911). This is the case with some Indigenous communities when they make efforts to revitalise or maintain an indigenous language (King, 2000; McCarty, 2011). King's (2000) study of Ecuadorian parents illuminates that "tensions can arise between conflicting explicit 
and implicit ideologies" (King et al., 2008, p. 911). She observed that community members' stated, explicit 'pro-Indigenous' ideology is often in conflict with a privately held, implicit 'anti-Indigenous' language ideology. The resulting conflict shapes home language practices that leads to community language shift. Such mismatches have also been observed in other minority language revitalisation contexts, such as Irish Gaaeltacht (Óhlfearnáin, 2013) and Australia (Simpson, 2013).

Ideology conflicts can be problematic for effective policy enactment. Kirsh (2012) interviewed and observed seven middle-class, Luxembourgish mothers who attempted to raise their children bilingually in Luxembourgish and English in Great Britain. Although these mothers strongly identified with Luxembourgish and recognised their role in ensuring exposure to Luxembourgish, living in a monolingual setting where the dominant language ideology emphasises English only has led to ideology clashes. This was reflected through the contradictory language practices at home in which mothers constantly accommodated children's language requests in English. Consequently, Luxembourgish input was reduced and the chances for raising active bilinguals were limited.

Much research into language practices has focused on parental discourse strategies and home language models that parents use in raising bilingual children. Lanza $(2004,2007)$, for example, identified five types of discourse strategy which parents use to socialise their children into a particular linguistic practice, including minimal grasp, expressed guess, repetition, move on and code-switch. These strategies demonstrate parental efforts in their conscious/explicit or implicit language planning decisions in their everyday interactions with children.

Everyday interactions not only can elucidate the hierarchical order of the languages related to different market values, but they also provide insights into the processes of language development, language shift and language change. Building on Lanza's (2007) work, Gafaranga (2010), studied language shift of Rwandans in Belgium. He observed that Kinyarwanda-French bilingual children constantly used 'medium request' to ask for medium-switch from Kinyarwanda to French when speaking to adults. During the process of medium request, language policy is negotiated where adults often accommodate children's requests, thus leading to language shift 
through face-to-face interactions. Also highlighting the role of linguistic practices in everyday interactions, Li Wei (2005) states that identity, attitudes and relationship can be accepted or rejected all in the process of interaction. Zhu Hua (2008)'s work on bilingual intergenerational talk illustrates that conflictual sociocultural values and identities are intensely negotiated, mediated and evaluated in bilingual interactions. Curdt-Christiansen (2013b), basing her work on discourse analysis of family talk in homework sessions, demonstrated that a range of FLPs are established and enacted in Singaporean Chinese bilingual families through parental discourse strategies, from highly organized and overt policies to unreflective, laissez-faire attitudes.

Taken together, the studies reviewed have yielded much insight into the interplay between language practices and language ideologies among family members. While recognising that both linguistic and non-linguistic forces account for language choice in home domains, more studies are needed to illuminate the specific processes or mechanisms whereby these forces come into play and relate to each other. Such research will enhance our understanding of how linguistic practices are established, FLP is enacted, cultural values are transmitted, and language and cultural practices are changed or discontinued in relation to societal changes and sociopolitical structures. It is particularly important to document why conflictual ideologies exist and how they are formed within a family, and what the implications are of these incongruent ideologies and inconsistencies in language practices.

\section{The Study}

The participating families

This study is part of a larger research project, investigating biliteracy environments of young children between 5 and 8 years old. For this article, I have chosen three families, a trilingual Chinese family, and a Malay and an Indian bilingual family, which represent the ethnic make-up of Singaporean society. As a common characteristic, all three families are typical, large, Asian-oriented families, for 
which 'family' is a unique, closely-knit concept where children, parents, grandparents, uncles and aunties all live under the same roof. The families' profile is presented in table 1.

\begin{tabular}{|c|c|c|c|c|}
\hline Family & Child/Age & Family Members & Adult Educational Level & Languages at Home* \\
\hline \multirow{6}{*}{$\begin{array}{l}\text { Family A } \\
\text { Chinese }\end{array}$} & \multirow{6}{*}{$\begin{array}{l}\text { Trevor } \\
7\end{array}$} & Grandma & No education & Hokkien, Mandarin \\
\hline & & Parents & Diploma & Mandarin, English, Hokkien \\
\hline & & Older sister & Primary 5 & English, Mandarin \\
\hline & & Elderly uncle & Elementary & Hokkien, Mandarin \\
\hline & & Aunt 2 & O'level & Mandarin, English, Hokkien \\
\hline & & & & Between Sibling: English, Mandarin \\
\hline \multirow{7}{*}{$\begin{array}{l}\text { Family B } \\
\text { Malay }\end{array}$} & \multirow{6}{*}{$\begin{array}{l}\text { Adena } \\
51 / 2\end{array}$} & Parents & $\mathrm{BA}$ & Malay, English \\
\hline & & Grandparents & Diploma + O'level & Malay, English \\
\hline & & Aunt 1 & Uni Student & English, Malay \\
\hline & & Aunt 2 & Uni Student & English, Malay \\
\hline & & $\begin{array}{l}\text { Younger } \\
\text { brother }\end{array}$ & Kindergartener & English (Malay) \\
\hline & & $\begin{array}{l}\text { Indonesian } \\
\text { helper }\end{array}$ & $\mathrm{n} / \mathrm{a}$ & Malay \\
\hline & & & & Between sibling: English \\
\hline \multirow{6}{*}{$\begin{array}{l}\text { Family C } \\
\text { Indian }\end{array}$} & \multirow{6}{*}{$\begin{array}{l}\text { Tobias } \\
5\end{array}$} & Parents & BA (teachers) & English, Tamil \\
\hline & & Grand parents & Diploma (teacher) & Tamil, English \\
\hline & & $\begin{array}{l}1 \text { younger } \\
\text { sister }\end{array}$ & kindergartener & English \\
\hline & & Uncle & Uni Student & English, Tamil \\
\hline & & Filipina helper & $\mathrm{n} / \mathrm{a}$ & English \\
\hline & & & & Between sibling: English \\
\hline
\end{tabular}

*Home languages are listed in the order of dominance and frequency of use.

Consisting of grandmother, parents, Second aunt, elderly uncle, and Trevor's older sister, Trevor's family was originally a Hokkien speaking family. While grandma, $2^{\text {nd }}$ aunt and uncle still speak mainly Hokkien, the rest of the family speaks more Mandarin and English. Trevor Teo is 7 years old and attends a neighborhood government school together with his sister, Tina (10 years old). During the week, Trevor and Tina are cared for largely by Second aunt while their parents go to work. Mr. Teo is a businessman and travels extensively in the region. Mrs. Teo works as an official in a government organization. Second aunt is a homemaker who takes care of grandma, uncle and the children. Trevor and Tina speak mostly English with each other. But they speak almost only Mandarin to Grandma. To parents, aunt and uncle, they code switch between Mandarin and English.

Adena, $5 \frac{1}{2}$ years old, is from a Malay family. She lives together with her grandparents, parents, two university student aunts and a younger brother, Mikki, 4 years old. Adena and Mikki go 
to a daycare center close to their home during the week. At the center, they are exposed to formal English classes similar to that of primary school where they are introduced to phonics. Adena's language repertoire is clearly influenced by the adults around her. Although she hears Malay from conversations among her grandparents and parents as well as the aunts, she speaks mostly in English to everyone, especially when she talks to her little brother, Mikki and her two aunts. When she speaks to her grandparents and the domestic helper, she uses Malay words dispersed in her conversation. Adena's Malay language, thus, can be said to be largely receptive.

Tobia is 5 years old and from a family of teachers. His grandparents are retired primary school teachers and his parents are currently teaching in two different government schools. His father, Mr. Rajan, holds a leadership position at secondary level while his mother, Mrs. Kavitha, teaches English, maths and science at a primary school. Tobia and his little sister, Tabitha aged 4, are cared of by their grandparents when the parents are busy with their teaching duties. Attending a private kindergarten, they are beginning to learn English in structured classes and are exposed to Mandarin despite of their Indian heritage. Tobia speaks English most of the time with everyone in the family, but he addresses his grandparents and his uncle in Tamil.

\section{Data sources}

For this article, three sets of data are included to capture FLP, including: 1) family language audit; 2) interview with parents; and 3) participant observation with recorded negotiation of FLP in face-toface social interactions.

The family language audit serves to capture the amount of different language input received and the types of language practiced by the children in a typical everyday situation. The audit form was distributed to families and a trial run was carried out with researchers. Then families filled out the form once per week during the period of data collection. The audit forms allow us to obtain information on how much time they use to practice the different languages and who are the interlocutors, in addition to the quality and quantity inputs to which children are exposed. 
The interview data is collected through two lengthy (30-40 minutes) recorded conversations with the parents, one at the beginning of the initial contact with the families, and one after a session or two observing the family language practices. Interviews were conducted in the mixed code based on the choice of the participants. Informal interactions with family members are also collected either through a recording device or by field notes depending on the family's permission and comfort with the device. These formal and informal interviews allow us to elicit parental ideologies towards bilingual policy and their perceived evaluation of the different languages in Singaporean society.

The interaction data is collected by employing ethnographical tools of inquiry through regular home visits once every two / three weeks depending on the family's availability. The families are given free choice to audio tape their interactions every week with or without the researchers' presence. Most recordings last between 10 to 30 minutes. The data allow us to capture the dynamics of the language repertoires of the family members which provides details on how family language policies are constructed and negotiated by both children and adults. This allows us to identify not only the different ideologies held by parents within the same family indexed by language practices, but also the incongruence between the parents' stated explicit language ideologies and implicitly conducted (communicated) language practice through language socialisation routines.

In what follows, I present the findings based on the recurring issues related to language ideologies and practices. Using discourse as an analytical tool, I then illustrate how family members project their meanings and positions with regard to language values and government policies. The findings are organized based on three aspects associated with language development, sociolinguistic reproduction and policy enactment: language learning environments; competing ideologies; and contradictions between ideology and practice.

\section{Findings}

Language Learning Environment - Family Language Audit 
Family language audit as a unit of analysis can provide valuable insights into the most

mundane routines and forms of everyday communicative practice - which also provide information about family linguistic environments for bilingual development. Following this line of analysis, De Houwer (2009) argues that language input is one of the most important variables contributing to the emergence of active bilinguals. In the following section, I present the language audit of each child and examine the characteristics of the linguistic environments. While the language audit provides important details, it should be noticed that the linguistic soundscape and input are loosely calculated in this context. It is an estimated measure of the language input we have gathered.

Trevor's linguistic activity

Table 2: Trevor's language audit

\begin{tabular}{|c|c|c|c|c|}
\hline Time & Activities & $\begin{array}{l}\text { People } \\
\text { Involved }\end{array}$ & $\begin{array}{l}\text { Language } \\
\text { used }\end{array}$ & Remarks \\
\hline 8 am & $\begin{array}{l}\text { Breakfast and play } \\
\text { with Ipad }\end{array}$ & Grandma. & $\begin{array}{l}\text { Mandarin } \\
\text { Hokkien }\end{array}$ & $\begin{array}{l}\text { Grandmother attends to } \\
\text { him for breakfast before } 2^{\text {nd }} \\
\text { aunt shows up at } 9 \text { am }\end{array}$ \\
\hline 9 am & $\begin{array}{l}\text { Study; homework; } \\
\text { revision }\end{array}$ & $2^{\text {nd }}$ aunt & $\begin{array}{l}\text { Mandarin } \\
\text { English }\end{array}$ & $\begin{array}{l}2^{\text {nd }} \text { aunt mainly teaches him } \\
\text { Chinese and sometimes } \\
\text { Maths. }\end{array}$ \\
\hline $10 \mathrm{am}$ & $\begin{array}{l}\text { Study; homework; } \\
\text { revision }\end{array}$ & $2^{\text {nd }}$ aunt & $\begin{array}{l}\text { Mandarin } \\
\text { English }\end{array}$ & $\begin{array}{l}\text { Until } 1030 \text { playtime. For } \\
\text { half hour. }\end{array}$ \\
\hline $11 \mathrm{am}$ & $\begin{array}{l}\text { Free Play } \\
\text { Ipad or toys }\end{array}$ & Self or & $\begin{array}{l}\text { English } \\
\text { Mandarin }\end{array}$ & $\begin{array}{l}\text { Grandma and } 2^{\text {nd }} \text { Auntie } \\
\text { prepare lunch }\end{array}$ \\
\hline $12-6 \mathrm{pm}$ & School & $\begin{array}{l}\text { Teacher/class } \\
\text { mates }\end{array}$ & $\begin{array}{l}\text { English } \\
\text { Except MT } \\
\text { lesson } \\
\end{array}$ & $\begin{array}{l}2^{\text {nd }} \text { Auntie sends him to } \\
\text { school }\end{array}$ \\
\hline $6 \mathrm{pm}$ & $\begin{array}{l}\text { Dinner } \\
\text { TV }\end{array}$ & $\begin{array}{l}\text { Grandma } \\
\text { Uncle }\end{array}$ & $\begin{array}{l}\text { Mandarin } \\
\text { Hokkien }\end{array}$ & Free conversation \\
\hline $7 \mathrm{pm}$ & Play or watch DVD & $\begin{array}{l}\text { Mother } \\
\text { Grandma } \\
\text { Uncle }\end{array}$ & $\begin{array}{l}\text { English } \\
\text { Chinese } \\
\text { Hokkien }\end{array}$ & Cartoon/drama series \\
\hline $8 \mathrm{pm}$ & Homework /Revise & Mother & English & \\
\hline $9 \mathrm{pm}$ & $\begin{array}{l}\text { Winds down before } \\
\text { sleep }\end{array}$ & Mother & English & $\begin{array}{l}\text { Bathe/Brush teeth/ play } \\
\text { Ipad }\end{array}$ \\
\hline
\end{tabular}


Trevor's typical day starts in Mandarin and Hokkien when grandma prepares breakfast for him before his $2^{\text {nd }}$ aunt comes in (see table $2^{1}$ ). This one hour breakfast period is the only time he is exposed directly to Hokkien. When $2^{\text {nd }}$ aunt comes in at 9 am, the conversation turns mostly into a mixed code of Mandarin and English. The comparatively intensive Mandarin exposure lasts about 1 $1 / 2$ hours. Trevor leaves for school which lasts from 12:15-6:00pm. The hours spent at school are largely in English except mother tongue class (about 30 minutes every day). When he comes back from school, he hears Mandarin and Hokkien as well as English spoken among the adults for about one hour. Then he is passively exposed to English through TV programmes for one hour. Following that, the homework time with his mother is exclusively in English. So in the total 13 hours of his time awake, Trevor's language exposure and practices are roughly: English 9hours; Hokkien 1hour; and Mandarin 3 hours.

Adena's Linguistic environments

Table 3: Adena's language audit

\begin{tabular}{|l|l|l|l|}
\hline Time & Activity & Interlocutor(s) & Language Spoken \\
\hline $\mathbf{7 . 1 5} \mathbf{~ a m}$ & $\begin{array}{l}\text { Breakfast with grandparents and } \\
\text { great-grandparents }\end{array}$ & $\begin{array}{l}\text { Grandparents } \\
\text { Great-grandparents }\end{array}$ & $\begin{array}{l}\text { English } \\
\text { Malay } \\
\text { Malay }\end{array}$ \\
\hline $\mathbf{8 . 0 0} \mathbf{~ a m}$ & Shower and gets ready for school & Grandparents & English \\
\hline $\mathbf{8 . 3 0} \mathbf{~ a m}$ & Walks to school & Grandparents & $\begin{array}{l}\text { English } \\
\text { Malay }\end{array}$ \\
\hline $\mathbf{8 . 4 0} \mathbf{~ a m ~ - 5 . 2 0 p m}$ & Attends child care & $\begin{array}{l}\text { Teachers } \\
\text { Classmates }\end{array}$ & $\begin{array}{l}\text { English \& Mandarin } \\
\text { (Mandarin is used } \\
\text { for songs only) }\end{array}$ \\
\hline $\mathbf{5 . 2 0 ~} \mathbf{p m}$ & Walks home from school & Grandparents & $\begin{array}{l}\text { Malay } \\
\text { English }\end{array}$ \\
\hline $\mathbf{5 . 3 0} \mathbf{~ p m}$ & Dinner & Grandparents & $\begin{array}{l}\text { Malay } \\
\text { English }\end{array}$ \\
\hline $\mathbf{5 . 5 5} \mathbf{~ p m}$ & Takes a shower & - & - \\
\hline
\end{tabular}

\footnotetext{
${ }^{1}$ Singapore's primary schools normally run two sessions - morning and afternoon. Trevor attends the afternoon session while his sister attends the morning session.
} 


\begin{tabular}{|l|l|l|l|}
\hline $\mathbf{6 . 1 0} \mathbf{p m}$ & $\begin{array}{l}\text { writings her ABCs and draws } \\
\text { Occasionally, she leaves her desk } \\
\text { to play with her younger brother. }\end{array}$ & Aunts & English \\
\hline $\mathbf{9 . 0 0} \mathbf{p m}$ & $\begin{array}{l}\text { Converses with her parents about } \\
\text { her day }\end{array}$ & Parents & English \\
\hline $\mathbf{9 . 3 0} \mathbf{p m}$ & $\begin{array}{l}\text { Grandmother tells a bedtime } \\
\text { story to her. She alternates } \\
\text { between English and Malay } \\
\text { stories on different days. }\end{array}$ & Grandparents & $\begin{array}{l}\text { English (60\%) } \\
\text { Malay (40\%) }\end{array}$ \\
\hline
\end{tabular}

Adena's daily language activities take place mostly in the day care centre. She spends eight hours in a largely English environment with an hour of Chinese language class where the teachers teach the children how to write simple Chinese characters and sing songs. The rest of her day, she is exposed to English (90\%) and Malay (10\%). Her total language activities include: English 9 hours; Malay 2 hours; and Mandarin 1 hour.

Tobia's linguistic environment

Table 4: Tobia's Language audit

\begin{tabular}{|c|c|c|c|c|}
\hline Time & Activities & People involved & Language (s) used & Remarks \\
\hline 9 am & $\begin{array}{l}\text { Wake up / bathe/ } \\
\text { breakfast }\end{array}$ & $\begin{array}{l}\text { Father, Mother, } \\
\text { Grandparents, } \\
\text { Helper } \\
\end{array}$ & English, Tamil & $\begin{array}{l}\text { Words used for bathing, } \\
\text { eating in Tamil (mix) }\end{array}$ \\
\hline $10 \mathrm{am}$ & $\begin{array}{l}\text { Play with toys, watch } \\
\text { cartoon (Disney) }\end{array}$ & & English & $\begin{array}{l}\text { Excitement expressions } \\
\text { in English }\end{array}$ \\
\hline $11 \mathrm{am}$ & $\begin{array}{l}\text { Play ball with grandfather } \\
\text { and uncle }\end{array}$ & $\begin{array}{l}\text { Grandfather } \\
\text { Uncle }\end{array}$ & English, Tamil & $\begin{array}{l}\text { Terms of endearment in } \\
\text { Tamil by Grandfather }\end{array}$ \\
\hline \begin{tabular}{|l|}
12 \\
noon
\end{tabular} & $\begin{array}{l}\text { Eat lunch, pack school bag, } \\
\text { put on uniform, socks and } \\
\text { shoes, walk to school or } \\
\text { grandfather cycles the } \\
\text { child to school }\end{array}$ & $\begin{array}{l}\text { Grandmother or } \\
\text { helper, } \\
\text { Grandfather }\end{array}$ & English, Tamil & $\begin{array}{l}\text { Grandmother uses } \\
\text { Tamil to give } \\
\text { instructions }\end{array}$ \\
\hline $\begin{array}{l}1-5 \\
\text { pm }\end{array}$ & In school & $\begin{array}{l}\text { Teachers and } \\
\text { friends }\end{array}$ & English & $\begin{array}{l}\text { Learn Chinese numbers } \\
\text { and songs for } 30 \\
\text { minutes during second } \\
\text { half of the day }\end{array}$ \\
\hline $5 \mathrm{pm}$ & $\begin{array}{l}\text { Comes back from school, } \\
\text { Tea break, watch tv and } \\
\text { play }\end{array}$ & $\begin{array}{l}\text { Grandparents } \\
\text { Little sister }\end{array}$ & English & $\begin{array}{l}\text { Grandmother gives } \\
\text { instructions in Tamil }\end{array}$ \\
\hline $6 \mathrm{pm}$ & $\begin{array}{l}\text { Takes shower and plays } \\
\text { with sisters or grandfather }\end{array}$ & $\begin{array}{l}\text { Grandparents } \\
\text { Little sister }\end{array}$ & English, Tamil & $\begin{array}{l}\text { Tamil for calling names } \\
\text { when they quarrel }\end{array}$ \\
\hline
\end{tabular}




\begin{tabular}{|c|c|c|c|c|}
\hline 7 pm & $\begin{array}{l}\text { Watches TV with father, } \\
\text { talks to mother about } \\
\text { school, and complains } \\
\text { about quarrels with little } \\
\text { sister }\end{array}$ & Parents & English & $\begin{array}{l}\text { Uses Tamil to address } \\
\text { people (respect) }\end{array}$ \\
\hline 8 pm & $\begin{array}{l}\text { Dinner, plays with his own } \\
\text { toys, talks about school } \\
\text { and counts numbers or } \\
\text { recites alphabet }\end{array}$ & $\begin{array}{l}\text { Father; Uncle; } \\
\text { Grandparents; } \\
\text { Helper; Little } \\
\text { sister }\end{array}$ & English, Tamil & $\begin{array}{l}\text { Practice reading } 2 / 3 \\
\text { times a week after } \\
\text { dinner }\end{array}$ \\
\hline 9 pm & $\begin{array}{l}\text { Watches Tamil } \\
\text { programmes in Vasantham } \\
\text { central with father, } \\
\text { grandparents and sister }\end{array}$ & $\begin{array}{l}\text { Father } \\
\text { Grandparents } \\
\text { Little sister }\end{array}$ & English, Tamil & \\
\hline $10 \mathrm{pm}$ & $\begin{array}{l}\text { Goes to bed with mother, } \\
\text { Mother reads bed time } \\
\text { stories }\end{array}$ & Mother & English & $\begin{array}{l}\text { Uses Tamil to ask for } \\
\text { (milk), feeling (sleepy) }\end{array}$ \\
\hline
\end{tabular}

Tobia's daily communicative routine comprises various activities in different languages, including playing games with grandparents, watching TV, playing football and reading stories. During the 13 hours of his active involvement in various communicative activities, he is exposed to English, Tamil and a few words in Mandarin. At home, the languages to which he is exposed are English and Tamil. Although he is spoken to in Tamil at home, the types of Tamil are mainly simple word or phrase elicitations. When he is at the day care centre, he is very much a mono-lingual English speaker. He learns Chinese at the day care centre for about 30 minutes and is encouraged by his parents to speak Chinese. His linguistic environments include approximately: English 9 1/2 hours; Tamil $2 \frac{1}{2}$ hours; and Chinese 30 minutes.

In all three cases, the language environments are distinctively 'unbalanced', with English taking a clearly prominent position in the children's life. In general, all children use about nine hours of English and 2-3 hours of their respective mother tongues in their everyday endeavours. English is used not only at school with teachers and friends, but also at home with family members for all kinds of activities albeit mixed with their respective mother tongues. While Adena and Tobia exclusively use English when they play with their siblings, watch TV and play games by themselves, Trevor uses both English and Mandarin during free play or iPad time. Also noticeable are the different interactional patterns with their grandparents and extended family members. Whereas 
Trevor uses mixed Mandarin and Hokkien with grandma, Adena and Tobia use mixed English and their MTs with their grandparents. It is evident form the data that English is the language of play, homework and story time, as well as the language used with parents and young aunts and uncle. The 'unbalanced' model of interaction and input, as De Houwer (2007) points out in her study of families in Flanders, will not provide sufficient language learning environments for raising active bilinguals.

\section{Conflicting ideologies within Families: Bilingual, Multilingual or English monolingual?}

Language as a conceived construct, in the participating parents' evaluated stance, can provide affordances and constraints for their children. The interview data clearly suggests that parents/caregivers perceive languages differently and that they have different ideologies towards a given language, even within the same family. In Trevor's family, for example, where different members of the family are involved in raising the children, they explicitly demonstrate conflicting views on the languages in their repertoire. (All interviews are transcribed and presented in their original language in plain font. Translation is provided directly under the original text in italics.)

\begin{tabular}{|c|c|}
\hline $2^{\text {nd }}$ Aunt & Mrs Teo (Mother) \\
\hline $\begin{array}{l}\text { 我觉得我们不应该忘本, 祖先是讲福建话, 福建话 } \\
\text { 是代表我们的文化和根。 } \\
\text { I think that it is important to remember our ancestor } \\
\text { and Hokkien is the language that marks our culture } \\
\text { and root. }\end{array}$ & $\begin{array}{l}\text { English is an international language for } \\
\text { work. It is the basic and everyone needs to } \\
\text { learn English. } \\
\text { It is okay so long as he (Trevor) knows how } \\
\text { to speak and write (Chinese). After all, } \\
\text { despite the government talking about } \\
\text { bilingualism, everything is in English. It will } \\
\text { be fine if he can speak a little and listen a } \\
\text { little but if he can't it is fine too. } \\
\text { Hokkien is not very important. Perhaps } \\
\text { when he buy [sic] drinks from the auntie, he } \\
\text { can use it but even then Mandarin can be } \\
\text { used. }\end{array}$ \\
\hline Mr Teo (Father) & Mrs Teo (Mother) \\
\hline $\begin{array}{l}\text { 我们以前没有给他机会学华文和福建话。以前就开始跟 } \\
\text { 他讲英语。没有平衡。很不应该。以前觉得英文很重 } \\
\text { 要, 学了华语和福建话会影响他的英文, 所以就跟他讲 } \\
\text { 华语掺英文。我们以前是不要他长大后像我们一样英文 } \\
\text { 烂。可是变成他在学校家里都用英文, 只有上华文的时 } \\
\text { 候才用华语。 } \\
\text { We didn't really give him opportunities to learn } \\
\text { Mandarin and Hokkien. We started using English }\end{array}$ & $\begin{array}{l}\text { I am okay with it (less proficient in } \\
\text { Mandarin). I will not stop him from learning } \\
\text { English in favour of Mandarin. After all, } \\
\text { English is still the dominant language in } \\
\text { Singapore and the world. And English is } \\
\text { becoming more and more important. This } \\
\text { was why I decided that I would speak }\end{array}$ \\
\hline
\end{tabular}


when speaking to him in the past. No balance [between Mandarin and English]. We shouldn't have done that. By then, we thought English was very important, and learning Mandarin and Hokkien could interfere with his English. So we started speaking to him in Mandarin mixed with English. That was because we didn't want him to grow up speaking bad English like us. It ended up with him using English both at school and at home. The only chance for him to use Mandarin is during his mother tongue lesson.
English to him. Even China is starting to speak English now. I will just make sure that he doesn't stop speaking Chinese.

In this focus group interview, a clear but very distinctly different view about the three languages involved in the family emerged. While Mrs Teo openly expressed her overt antipathy towards learning Hokkien, Aunt 2 and Mr Teo felt a sense of regret for not providing Trevor with the opportunity for developing his Hokkien. Despite their beliefs of Hokkien as "the language that marks our culture and root", they nonetheless had chosen to speak English with Trevor because they were convinced "English was very important, and learning Mandarin and Hokkien could interfere with his English". The sense of regret revealed an implicit but publicly acknowledged hierarchical rank of the languages in Singapore with 'dialects' at the bottom, Mandarin in the middle and English on top. 'Dialects' have been depicted as underdeveloped language varieties and dialect speakers have been associated with poor or little education (Li, et al., 1997). Because of the lower 'value' in Hokkien, Mrs Teo reckoned that Trevor only needed to use it when buying drinks from aunties (drink sellers in food courts), but "even then Mandarin can be used".

Unintentionally, Mr Teo's acknowledgement of providing 'unbalanced' opportunities for Trevor's Mandarin practices revealed a deeper layer of the sociopolitical reality in Singapore brought about by the bilingual policy where success in school and life is evaluated by a person's level of English proficiency. Although the bilingual policy requires children to study both English and MT, most jobs both in the public and the private sector require only English knowledge unless the employment is directly related to a specific language, such as trade with China or India.

In this linguistic market English, Mandarin and Hokkien are clearly positioned hierarchically. This hierarchical linguistic reality has caused conflictual attitudes in many families and parents as 
they would like to adhere to their own culture and language on the one hand, but have to be proficient in English on the other because of educational and economic pressures. Consequently, parents tend to make 'convenient' decisions about 'losing' Mandarin. As expressed by Mrs Teo, "it will be fine if he (Trevor) can speak a little and listen a little but if he can't it is fine too". After all, as she articulated "despite the government talking about bilingualism, everything is in English".

Clearly, the disparate views between the pro- (Mr Teo and $2^{\text {nd }}$ Aunt) and anti- (Mrs Teo) Mandarin/Hokkien were also manifested in their daily language practices with different members of the family as evidenced by Trevor's 'unbalanced' linguistic exposure to Mandarin and Hokkien. While a positive attitude is crucial for the intergenerational language transmission in the home, family members are inevitably influenced by negative ideologies in public discourse. King (2000) argues that such negative ideologies could be derived from a deep rooted belief in the inferiority of indigenous language or 'dialects' and the superiority of a powerful European language such as English. In Singapore, 'dialects' have been negatively associated with being 'vulgar', 'stagnant' and 'unrefined' in public and political discourses openly (Lim, 2009). In the following dialogue, Grandma Teo receptively pointed out that the language shift phenomenon is complex and FLP is indirectly related to "a wide range of socio-historical, political, cultural and linguistic variables" (CurdtChristiansen, 2013, p.1).

这阵佇新加坡红毛真重要。找工啦，或系做舍物物件。永摆我无读册，册晓讲红毛， 要是爱找工就真艰苦。但系这阵少年的无相象。永摆我侬讲福建话，恁父母的时阵讲 福建话加华语, 这阵你侬就讲红毛加华语 (Interview is in Hokkien, but transcribed in Chinese characters)。

English is so important in Singapore whether at work or in other settings. I did not go to school so I did not receive any education or know any English and so it would be hard if I want to find a job. Every generation develops differently. In our generation it was Hokkien, during your parent's generation it was Hokkien and Mandarin and now it is mostly English and some Mandarin.

In Adena's family, similar conflicting ideologies are found among the adults involved in her life. The following juxtaposition illustrates the different language ideologies expressed by Adena's mother, her $1^{\text {st }}$ auntie and $2^{\text {nd }}$ auntie. 


\begin{tabular}{|l|l|l|}
\hline \multicolumn{1}{|c|}{ Mother (Mrs. Amin) } & \multicolumn{1}{|c|}{ Aunt 1 } & \multicolumn{1}{c|}{ Aunt 2 } \\
\hline $\begin{array}{l}\text { Speaking Malay is } \\
\text { very important to } \\
\text { keep our culture and } \\
\text { it is what makes us } \\
\text { Malay. }\end{array}$ & $\begin{array}{l}\text { I think it is important to } \\
\text { speak Malay at home but it } \\
\text { is also important to speak } \\
\text { English to my little niece. } \\
\text { When they go to school, } \\
\text { they have to communicate in } \\
\text { English. }\end{array}$ & $\begin{array}{l}\text { I think maintaining the use of home } \\
\text { language is not as important as introducing } \\
\text { and exposing my niece to English language } \\
\text { especially in this ever demanding education } \\
\text { system in Singapore. They will be entering } \\
\text { Primary 1 next year therefore the need to } \\
\text { be able to speak, understand and write in } \\
\text { English is becoming more urgent. If they are } \\
\text { not able to grasp English language well, } \\
\text { they will have a hard time catching up to } \\
\text { the other students who are able to speak } \\
\text { and write in English. As a result, they might } \\
\text { need additional help and be in the Learning } \\
\text { Support Program for reading. }\end{array}$ \\
& \multicolumn{2}{|l}{}
\end{tabular}

The contrast between Adena's mother and her two aunties evidently suggests that Malay and English play different roles in their family. While Mrs. Amin firmly believed that the Malay language was "what makes us Malay", her two younger sisters were more concerned with Adena's English proficiency. There is a clear demarcation in the domain of use between Malay and English. For the two young aunts (both university students), Malay was the language of home, with little wider functional utility for passing on to the next generation. Acknowledging the importance of speaking Malay at home, the $1^{\text {st }}$ aunt made a strong point emphasizing speaking English was not a choice but a necessity. Resonating with her sister, the $2^{\text {nd }}$ auntie was convinced that maintaining Malay "is not as important as introducing and exposing my niece to English language". Like Trevor's mother, she was also deeply concerned about her niece's education in English. Her worries about the "demanding education system in Singapore", fears of having "a hard time catching up to [with] other students" and concerns about ending up in the "learning support programme" ${ }^{2}$ revealed a deep sense of uncertainty about developing Malay. Once again, the power of English imposed by the bilingual policy and manifested in socio-economic, political and educational practices has 'coerced'

\footnotetext{
${ }^{2}$ Learning Support Programme (LSP) is a reading programme designed for children in grade 1-3 with English learning 'difficulties'.
} 
parents and caregivers to give up the peaceful coexistence of mother tongue and English. In the making of their FLP, they have to negotiate the linguistic loyalty with the educational reality.

Ideology and Practice: Congruent or Incongruent?

The results of FLP negotiation between educational reality and linguistic continuity are dynamic and complex in these families, revealing both congruent and incongruent patterns. In the following, I demonstrate how such (in)congruencies are manifested in their daily linguistic practices and in the perceived values of different languages.

The following dialogue took place when Adena and her little brother were playing games on an iPad. They disagreed on which apps to download and what games to play. [A=Adena; $M=$ Mother; ibu=mother in Malay; Mi=younger brother Mikki; Bold text=code-switched items]

\begin{tabular}{|l|l|}
\hline \multicolumn{1}{|c|}{ Ideology } & \multicolumn{1}{|c|}{ Practice } \\
\hline It's very easy to speak in English. But certain things & A: I wan the er ibu [mother in Malay] \\
when you say in Malay, it has more meaning. Or like & M: taking turns. What's that? Banana app \\
when you scold in Malay or like maybe when they are & M: oo the talking dinosaurs! \\
bigger, if I say to them if I scold them in Malay & A: nono (Mikki is changing the app) \\
because it's like very endearing. It's like you can scold & Mi: see. (Mikki shows his mother the app) \\
them yet it's not so formal, right.? It's like you can tell & A: don't mama \\
them how disappointed you are and how sad you & M: Sayang (stroking Adena)[love in Malay] \\
really are. But when you say in mother tongue, it's & A: I love Sophiana... \\
like really ahh. & \\
$\qquad$ \\
\multicolumn{2}{|c}{ (interview with Mrs. Amin) } \\
\end{tabular}

In this interview, Mrs. Amin indirectly acknowledged that English has a major social function in this family. Concomitantly, she gave also recognition to the Malay language, valuing it as the language of emotion and intimacy. Indeed, as a type of FLP establishment, parents tend to convey emotions through praise and discipline, love and instructions (Pavlenko, 2004). While describing the language as having 'more meaning' and being 'endearing', our observations and recorded dialogues indicate little such uses in their daily communications. Examining the interactions carefully, we found that only the term of address was frequently used in Malay among the family members as 
shown in the conversation above. The entire dialogue was conducted in English except when Adena addressed her mother as 'ibu' and Mrs. Amin called her 'sayang'.

In a recent study of Irish language revitalization, Ó hIdearnáin (2013) argues that effective intergenerational language transmission does not occur without specific strategies, even when parents have strong linguistic ability in the minority language. Our data suggests that the habitual linguistic practice, translated from overt and hidden ideological convictions, failed to build a 'language reproduction' line. In the next excerpt, I demonstrate how linguistic choices as an input source shapes the language practices of the younger Amins.

1 A: There's something in my nose.

M: Oh. Having nose problem?

M: (to domestic helper) Bikkkk, kasi dia deir purple medicine (give her the purple medicine).

Mi: $\quad$ gasik deir purple medicine. [mimicking his mother]

$5 \quad$ M: Full of nonsense ah.

Mi: Ah ah. Give deir purple medicine al.

A: $\quad$ er you Malay or what?

M: Why don't you speak Malay? See whether she understands.

Mi: $\quad$ saya ayam di katak (my chicken at frog) [sounds out different words in Malay] 10 M: ayam ayam gorent! (fried chicken) [correcting Mikki].

In this conversation, it is noticeable that English is the preferred language of choice between Mrs. Amin and her children, indicating a habitual and de facto language practice in this family. From her rich linguistic repertoire, Mrs. Amin chose Malay with the helper (line 3). In this case, it was a translanguaging mode of communication (Garcia \& Li Wei, 2014). In line 4, Mikki tried to mimic his mother, but failed to produce the correct words. Instead of providing the correct input in Malay, Mrs. Amin employed a move on strategy (Lanza, 2004), acknowledging her understanding of the context and giving consent indirectly to Mikki's mimic. Annoyed by her little brother's behavior, Adena challenged Mikkie to speak more Malay. Subsequently, Mikki produced a meaningless sentence by stringing some randomly chosen Malay words together - saya ayam di katak (my chicken at frog). The conversation clearly indicates that the input pattern from parents to children is a decisive factor in children's language output (de Houwer, 2007). The inconsistency between Mrs. 
Amin's expressed pro-Malay ideology and her 'English only' practice reminds us that FLP is not a decontextualized psycholinguistic practice; rather, it is constantly interacting with and shaped by overt language policies at institutional levels and covert long-standing negative ideological associations with minority languages at family level.

\section{Illusory FLP: Contradictory Linguistic Practices and Expectations}

In light of the competing ideologies and contradictory language practices, it is not difficult to understand that Singapore is undergoing a visible language shift from MTs to English, and that many parents see raising bilingual children as a challenging endeavour. Despite the inconsistencies, some parents still have high expectations for their children's linguistic proficiency. Tobia's mother, for example, expressed herself as such a parent,

I think that bilingual education is the trend of Singapore's education system and it's been in place for a very long time. It is import for us to uphold it as well. We all take English as our first language as it is the official language of communication, work and business. At the same time our mother tongue is very important for us because it's closely associated with our culture, race, tradition, values and identity as an individual. Thus learning both languages helps us to be effective bilinguals. I want my child to be a good bilingual as well by speaking and writing both English and Tamil at a high standard level.

Interview with Tobia's mother, Kavitha

Kavitha's testimonial is an echo of the government's official policy statement. When asked about her opinion on the bilingual policy, she conformed her beliefs with the government's ideological valorisation of English as the 'First language' and mother tongue as the cultural affiliation. Firmly believing that bilingualism is beneficial for her children, she articulated that "I want my child to be a good bilingual as well by speaking and writing both English and Tamil at a high standard level". While the definition of 'a good bilingual' and 'a high standard level' in speaking and writing English and Tamil can be interpreted differently from individual to individual, there is no doubt that Kavitha expected her child to become a competent, if not a 'balanced', bilingual. The strong emotive expression 'I want' illustrates her firm 'impact beliefs' in raising bilingual children. But was this expectation compatible with her family language policy? The following interaction 
excerpt illustrates the linguistic inputs given and efforts made to ensure that Tobia will become 'a good bilingual’.

The context of the excerpt is story time reading where Tobia was reading The Farm Concert by Joy Cowley. [T=Tobia; U=uncle; G=Granny; Bold text=code-switched items]

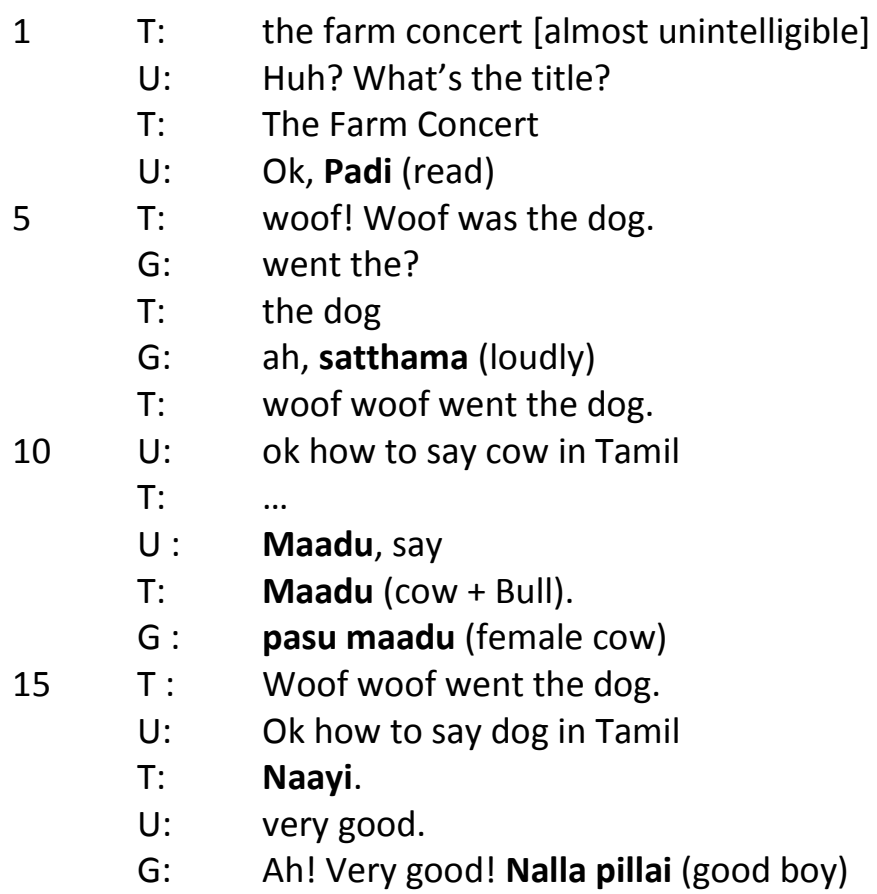

In this story reading session, we have a sense of how Tamil is used and practiced in the family. Tobia picked up The Farm Concert and started reading in an unintelligible pronunciation. Slightly annoyed, his uncle made a request asking him "what is the title?" Tobia then complied with the request by enunciating the title clearly. Noticeable from the exchanges are the instructions given by the uncle and granny in Tamil, line 4 "Padi (read)" and line 8 "satthama (loudly)". This suggests that Tobia is following a developmental trajectory that exposes him to partial linguistic structures in Tamil. In the succeeding section of interchanges, his uncle repeatedly used a simply vocabulary elicitation strategy for Tobia's Tamil acquisition, as in line 10, "how do you say cow in Tamil" and line 14 "how do you say dog in Tamil". This type of vocabulary ventriloquation, found typically in initial foreign language instruction classes, seems to indicate that Tobia uses little Tamil as a communication language. It also suggests that the default language in the family may be primarily 
English, as shown in the unmarked code of communication. Although the parents and adults in the family may believe that they use Tamil or a translingual code of Tamil and English, they use nonetheless mainly English when communicating with Tobia and his sister.

In the course of this brief reading episode, both the uncle and granny took on a foreign language instructor's role in teaching Tobia Tamil. The identity of Tobia is no more than that of a beginner learner. The exchanges reveal a fundamental issue of FLP regarding both quality and quantity of language input provided by parents or other members of the family. Admittedly, Tobia would be able to learn a few vocabularies in Tamil through vocabulary ventriloquation, but to "become a good bilingual as well by speaking and writing both English and Tamil at a high standard level" is an unrealistic expectation of the parents. Vocabulary ventriloquation provides neither width nor depth of language structures, grammar complexities and vocabulary varieties sufficient for bilingual development. While scholars like King (2000) and Dauenhauers (1998) have pointed out more than a decade ago that becoming a competent language user "cannot be done to one or for one by others" (Dauenhauers, 1998, p. 97), I would argue that the incompatibility of practice and expectation could be a cry for intervention by others - the state and the schools - to provide adequate structures and facilities for MT development as well as ideological support for families battling against language shift.

\section{Discussion and Conclusion}

In this article I use three families that represent Singapore's ethnic makeup to illustrate how conflicting ideologies and contradictory practices are at work within families. Three types of conflicts are identified among these families: conflicting ideologies, contradictions between ideologies and practice, and contradictions between practices and expectations. These conflicts and contradictions offer new insights into the processes of language shift and development as they engage with broader experiences of the participating families in relation to political ideological orientations and attitudes to social institutions. 
Conflicting ideologies within families arise from the parents'/caregivers' different concerns about their children's identity, education and survival in a competitive society. These conflicts are difficult to resolve as they index the participants' different views on ethnic identity and cultural practice invoked by the bilingual policy which gives priority and higher status to English. With regard to contradictions between expressed attitudes and actual linguistic practices, the data again suggest that the overt language policy that favours English language, the pragmatic concerns about children's educational achievement, and the overriding weight of the economic value associated with English have 'coerced' the parents/caregivers to explicitly and implicitly, deliberately or unintentionally, choose the preferred code in their everyday linguistic practices.

The inconsistencies between language ideology and linguistic practices are also manifested in parental expectations. While the relationship between language and culture is explicitly recognised, and the instrumental values and educational benefits of bilingual education are convincingly confirmed, the efforts that parents made through everyday communicative practice are incongruent with their high expectations and impact beliefs. In reality, the 'lack' of commitment to such bilingual policy and unrealistic expectations require us to question what a bilingual person is, what an effective bilingual person is, and how a high standard of reading and writing can be achieved in two languages.

In settings where education involves two codes such as English and a local language (minority language), it is vital to make visible the ideological relationship between English and the mother tongue. In the context of Singapore, we need to question the dichotomised view of English as having instrumental values and mother tongues as having cultural functions (Curdt-Christiansen, 2014a; 2014b). Such a dichotomised view, when reflected in educational opportunity and social mobility, unquestionably and inevitably leads to reluctance in mother tongue language practice. Thus, communicative practices reflect sociohistorical trajectories and ideologically informed ways of conducting personal encounters. Curdt-Christiansen (2014a, p. 23) argues that when parents are faced with the question of which language to practice in a context where, 
[A]Il school subjects are taught in English and financial benefits are awarded to those who master English, what can be expected of parents? After all, parents do not want their children to fall behind in their academic performance and be unemployed or have lowincome careers.

It is not difficult to understand these conflicting ideologies and contradictory practices because linguistic practices and exchanges invoke a complex system of power relations. In Bourdieu's sense, language is a form of capital which has the capacity to produce material and symbolic values in a given linguistic market.

The linguistic market in Singapore reminds us that intergenerational linguistic transmission is not problem-free. Although parents have the linguistic competences in mother tongue language, and despite the fact that they hold positive attitudes towards mother tongues, the unspoken and implicit ideologies of language can "constrain people's everyday communicative practices, which in turn engender specific linguistic and sociocultural outcomes" (Garrett, 2011, p. 519). This sociopolitical reality acts as "specific sanctions and specific censorship" (Bourdieu and Wacquant $1992,145)$, producing a powerful system of forces that constantly evaluate the values of linguistic products. When caregivers' deliberate/unintentional language choice, enacted in everyday mundane interactions, involves preference towards a language of wider communication, access to mother tongue languages can be greatly compromised. When that happens, language shift becomes inevitable.

\section{References:}

Blommaert, J. (2006). Language policy and national identity. In T. Ricento (Ed.), An introduction to language policy: Theory and method (pp. 238-254). Malden, MA: Blackwell.

Canagarajah, A. S. (2011). Diaspora communities, language maintenance, and policy dilemma. In Ethnography and Language Policy, T.L. McCarty (ed.), 77-97. London and New York: Routledge.

Chew, P. (2014). From multilingualism to monolingualism. Linguistic management in Singapore. In K. Sung \& B. Spolsky (eds.), Conditions for English Language Teaching and Learning in Asia (pp. 1-16). Newcastle upon Tyne, UK: Cambridge Scholars Publishing. 
Curdt-Christiansen, X.L. (2009). Visible and invisible language planning: Ideological factor in the family language policy of Chinese immigrant families in Quebec. Language Policy, 8(4), 351375.

Curdt-Christiansen, X.L. (2013a). Editorial: Family language policy: Realities and continuities. Language Policy, 13(1), 1-7.

Curdt-Christiansen, X. L (2013b). Negotiating family language policy: Doing homework. In M. Schwartz \& A. Verschik (eds); Successful family language policy: parents, children and educators in interaction (pp. 277-295). Series Multilingual Education 7. Dordrecht, Netherlands: Springer. DOI 10.1007/978-94-007-7753-8_10.

Curdt-Christiansen, X.L. (2014a). Planning for development or decline? Education policy for Chinese language in Singapore. Critical Inquiry in Language Studies, 11(1), 1-26.

Curdt-Christiansen, X. L (2014b). Family language policy: Is learning Chinese at odds with leaning English in Singapore. In X.L. Curdt-Christiansen and A. Hancock (Eds.); Learning Chinese in Diasporic communities: Many pathways to being Chinese (pp.35-58). John Benjamins.

Dauenhauer, N.M. \& Dauenhauer, R. (1998). Technical, emotional, and ideological issues in reversing language shift: Examples from Southeast Alaska. In L.S. Grenoble and L.J \& Whaley (eds.); Endangered languages: Current issues and future prospects (pp. 57-116). Cambridge University Press.

De Houwer, A. (1999). Environmental factors in early bilingual development: The role of parental beliefs and attitudes. In Extra, Guus and Ludo Verhoeven (eds.) Studies on Language Acquisition (pp. 75-95). Berlin, New York: Mouton de Gruyter.

De Houwer, A. (2007). Parental language input patterns and children's bilingual use. Applied Psycholinguistics, 27, 411-424.

De Houwer, A. (2009). Bilingual first language acquisition. Clevedon, UK: Multilingual Matters.

Fishman, J. A. (2004). Language maintenance, language shift, and reversing. In The Handbook of Bilingualism, T.K. Bhatia and W. Ritchie (eds), 406-436. Oxford, UK: Blackwell.

Gafaranga, J. (2010). Medium request: Talking language shift into being. Language in Society, 39(2), 241-270.

Gal, S. \& Woodlard, K. (2001)(eds.). Language and publics: The making of authority. Manchester, UK: St. Jerome Publishing.

Garcia, O. \& Li, Wei. (2014). Translanguaging: Language, bilingualism and education. Basingstoke, UK: Palgrave MacMillan.

Gupta, A. (2008). The language ecology of Singapore. In A. Creese, P. Martin \& N. Hornberger (eds.), Ecology of language (pp. 99-112). New York and London: Springer.

King, K. A. (2000). Language ideologies and heritage language education. International Journal of Bilingual Education and Bilingualism, 3(3), 167-184.

King, K.A. \& Fogle, L. (2006). Bilingual parenting as good parenting: Parents' perspectives on family language policy for additive bilinguals. International Journal of Bilingual Education and Bilingualism, 9(6), 695-712.

King, K. A., Fogle, L., \& Logan-Terry, A. (2008). Family language policy. Language and Linguistics Compass, 2(5), 907-922.

Kirsch, C. (2012). Ideologies, struggles and contradictions: An account of mothers raising their children bilingually in Luxembourgish and English in Great Britain. International Journal of Bilingual Education and Bilingualism, 15(1), 95-112. 
Kroskrity, P. (2010). Language ideologies - evolving perspectives. In J. Jaspers, J. Őstaman \& J. Verschueren (eds.), Society and language use (pp. 192-211). Amsterdam: John Benjamins.

Lane, P. (2010). We did what we thought was best for our children: A nexus analysis of language shift ina Kvan community. International Journal of Social Language, 202, 63-78.

Lanza, E. (2004). Language Mixing in Infant Bilingualism: A Sociolinguistic Perspective. Oxford: Oxford University Press.

Lanza, E. (2007). Multilingualism in the family. In P. Auer and Li Wei (Eds.), Handbook of multilingualism and multilingual communication (pp. 45-67). Berlin: Mouton de Gruyter.

Li, Wei. (1994). Three Generations Two Language One Family: Language choice and language shift in a Chinese community in Britain. Clevedon: Multilingual Matters

Li, Wei. (2011). Moment analysis and translanguaging space: Discursive construction of identities by multilingual Chinese youth in Britain. Journal of Pragmatics, 43, 1222-1235.

Li, W., Saravanan, V. \& Ng, J. (1997). Language shift in the Teochew community in Singapore: A family domain analysis. Journal of Multilingual and Multicultural Development, 18(5), 364384.

Lim, L. (2009). Beyond fear and loathing in SG: The real mother tongues and language policies in multilingual Singapore. AlLA Review, 22, 52-71.

McCarty T.L. (2011)(ed.), In Ethnography and Language Policy. London and New York: Routledge.

MOE (Ministry of Education) (2012). Education in Singapore. Retrieved 6 June 2013, from http://www.moe.gov.sg/about/files/moe-corporate-brochure.pdf

Okita, T. 2002. Invisible work: Bilingualism, language choice and childrearing in intermarried families. Amsterdam: John Benjamins.

Ó hlfearnáin, T. (2013). Family language policy, first language Irish speaker attitudes and communitybased response to language shift. Journal of Multilingual and Multicultural Development, 34(4), 348-365.

Pavlenko, A. (2004). 'Stop doing that, La Komu Skazala': Language choice and emotions in parentchild communication. Journal of Multilingual and Multicultural Development, 25(2 \& 3), 179203.

Pérez Báez, G. (2013). Family language policy, transnationalism, and the diaspora community of San Lucas Quiaviní of Oaxaca, Mexico. Language Policy, 12 (1), 27-45.

Seloni, L. \& Sarfati, Y. (2013).Trans)national language ideologies and family language practices: a life history inquiry of Judeo-Spanish in Turkey, Language Policy, 12 (1), 7-26.

Schiffman, H. (2006). Language policy and linguistic culture. In T. Ricento (Ed.), An introduction to language policy: Theory and method (pp. 111-125). Oxford, UK: Blackwell Publishing.

Shohamy, E. (2006). Language Policy: Hidden Agendas and New Approaches. London and New York: Routeledge.

Simpson, J. (2013). What's done and what's said: language attitudes, public language activities and everyday talk in the Northern Territory of Australia. Journal of Multilingual and Multicultural Development, 34(4), 383-398. 
Singapore Statistic. (2010). Census of population 2010. Retrieved 17 March 2010, from http://www.singstat.gov.sg/pubn/popn/c2010asr/10A1.pdf

Spolsky, B. (2004). Language policy. Cambridge: Cambridge University Press.

Zhao, S. \& Liu, Y. (2010). Chinese education in Singapore: Constraints of bilingual policy from the perspectives of status and prestige planning. Language Problems and Language Planning, 34(3), 236-258.

Zhao, S. \& Liu, Y. (2008). Home language shift and its implications for language planning in Singapore: from the perspective of prestige planning. The Asia Pacific-Education Researcher, 16(2), 111-126.

Zhu, Hua. (2008). Duelling Languages, Duelling values: Codeswitching in bilingual intergenerational conflict talk in diasporic families. Journal of Pragmatics, 40, 1799-1816. 